Seizing the moment

\author{
Russia's commendable attempt to revamp science in its universities must not \\ be confounded by the old guard.
}

T he Kremlin's apparently sincere efforts to refurbish the Russian science base will soon be put to the test. A new 12-billion-rouble (US\$390-million) programme, which aims to attract highprofile scientists to Russian universities (see Nature 465, 858; 2010), is to announce which projects have secured funds.

The competition, launched in July, is a unique opportunity to get Russia back on the global map of science - but it will also attract opportunists drawn to the money on offer.

The grants will be allocated by a panel run by Andrei Fursenko, the formerly politically marginal education and science minister. Unlike his post-Soviet predecessors, Fursenko has reasonable power over spending. But it will take more than money to retool the Russian science system to favour excellence, competition and mobility. A serious attempt must be made to push notoriously inert academic powers - including the influential Russian Academy of Sciences (RAS) - to accept and adopt the necessities of modern science.

Fursenko will announce 80 projects by November, each linked to an experienced individual scientist and chosen to receive up to 150 million roubles over the next two years. More than 500 groups - drawn from 214 of Russia's 650 or so state-funded universities - have responded to the ministry's call for proposals, including around 50 Western scientists and expatriate Russian researchers who are willing to spend significant time at a Russian university lab, as the programme rules require.

That is a respectable number. But organizational problems and a lack of proper advertising mean that the programme, designed to boost university research in all fields of science, has failed to attract the attention of many of the desired international scientific heavyweights. The few weeks given to applicants to approach project partners, inside and outside Russia, and to write proposals, was too short for scientists unfamiliar with Russian bureaucracy and institutions. As a result, foreign participation has been limited to the small numbers of scientists with well-established links to Russian labs.

Time constraints imposed by the Kremlin — its politicians are keen for results before the presidential election in 2012 - could also hamper the selection and work of foreign reviewers, whom the science ministry is desperately trying to recruit. At a round-table discussion last week in Moscow, Fursenko was still unable to name the line-up of European and US research organizations that will assist the review process.

Even so, the programme can make a difference. The inclusion of international review and the requirement to submit grant proposals in English are close to a revolution for an academic environment riddled with parochialism and isolationism (see Nature 464, 141-142; 2010). Western scientists and science organizations should acknowledge the emerging new spirit and participate as reviewers if asked.

Analysts close to the science ministry estimate that just 50-100 of the grant applications received can be considered internationally competitive research. The rest may not be pure junk, but it is an open secret that the ministry's money has attracted scientists who trade more on past reputation than research activity. There are thus concerns that RAS members on the 17-strong grant board might support
"It will take more than money to retool the Russian science system to favour excellence, competition and mobility." second-rate projects proposed by colleagues more interested in padding their salaries than establishing labs to carry out top-notch science.

This must not happen, even if it means that fewer than 80 projects get funded. And Fursenko, who has a reputation as a straight operator, must firmly rebuff any attempts to dilute or bypass the review process. That a number of Russian academics with less than stellar reputations have been removed from the initial list of reviewers is a promising sign. For the sake of transparency, and to counter any remaining suspicion of bias or favouritism, Fursenko should ensure that all grant applicants receive anonymized copies of the review reports that inform the board's funding decisions.

There are plenty of experienced mid-career Russian scientists who deserve to win funds. And a number of high-profile Western researchers are happy to dedicate time and effort to build capacity at Russian universities. If wisely spent, Fursenko's grants could have an impact far beyond the Russian border.

\section{An alternative route}

\section{A proposed road through the Serengeti can be halted only by providing a viable substitute, not by criticism.}

ootball fans who watch the televised English Premier League match between Stoke City and West Ham United on Saturday may get an urge to visit Tanzania. Adverts in Stoke's Britannia Stadium will tout the country's attractions, including the Serengeti National Park.

Home to an iconic wildebeest migration, the Serengeti is one of the most valuable ecosystems on the planet. So why does President Jakaya Kikwete of Tanzania want to build a road through it?

In an Opinion piece on page 272, 27 conservation experts warn that the proposed road could drive the entire Serengeti ecosystem to collapse by interrupting or diverting migration routes. No more wildebeest migration. No more tourists. The consequences seem dire.

Plans for a road across the Serengeti have been rejected on environmental grounds before. The World Bank refused funds in the 1980s, and impact assessments by external consultants in the 1990s found that the probable damage was too high a price for transport convenience.

Yet, in late July, Kikwete confirmed that his government would 